\title{
Variation in subcapsular liver structure and its significance in the interpretation of wedge biopsies
}

\author{
M. PETRELLI AND P. J. SCHEUER
}

\author{
From the Department of Pathology, Royal Free Hospital, Gray's Inn Road, London
}

SYNOPSIS Wedge biopsies from the inferior border of the normal liver were studied in 72 cases. They were divided into three groups according to the extent and degree of capsular and subcapsular fibrous tissue. The changes were not sufficiently severe or extensive to cause confusion with nodular cirrhosis or to make wedge biopsy unreliable as a diagnostic tool.

Operative biopsy of the liver is widely used for the diagnosis of liver disease. It is particularly valuable in such conditions as primary biliary cirrhosis and macronodular cirrhosis, in which a needle biopsy may give inadequate information. Variation in the structure of the liver immediately beneath the capsule may give rise to difficulty in interpretation. In this study the variation in structure is therefore analysed and its relation to true cirrhotic changes investigated.

\section{MATERIAL AND METHODS}

Seventy-two cases were studied at necropsy, 48 of them

TABLE I

\section{GROUP 2 CASES}

\begin{tabular}{|c|c|c|c|}
\hline Age & $\operatorname{Sex}$ & $\begin{array}{l}\text { Liver } \\
\text { Weight }(g .)\end{array}$ & Cause of Death Given by Pathologist \\
\hline 20 & $\mathbf{M}$ & 1,701 & $\mathrm{CO}$ poisoning; fire fumes \\
\hline 21 & $\mathbf{M}$ & 1,531 & $\mathrm{CO}$ poisoning; fire fumes \\
\hline 22 & $\mathbf{F}$ & 1,191 & $\mathrm{CO}$ poisoning; fire fumes \\
\hline 24 & $\mathbf{M}$ & 1,417 & Laceration of liver; multiple injuries \\
\hline 26 & $\mathbf{F}$ & 1,927 & $\begin{array}{l}\text { Pulmonary embolism; deep vein throm- } \\
\text { bosis }\end{array}$ \\
\hline 26 & $\mathbf{F}$ & 1,644 & $\mathrm{CO}$ poisoning; fire fumes \\
\hline 27 & $\mathbf{M}$ & 1,814 & $\mathrm{CO}$ poisoning; fire fumes \\
\hline 31 & $\mathbf{M}$ & 1,814 & $\mathrm{CO}$ poisoning; fire fumes \\
\hline 42 & $\mathbf{M}$ & 1,417 & HCN poisoning \\
\hline 49 & $\mathbf{M}$ & 1,790 & Chronic bronchitis and emphysema \\
\hline 54 & $\mathbf{F}$ & 1,100 & Pontine haemorrhage \\
\hline 55 & $\mathbf{M}$ & 2,480 & $\begin{array}{l}\text { Left ventricular failure; coronary throm- } \\
\text { bosis }\end{array}$ \\
\hline 58 & $\mathbf{M}$ & 1,814 & Myocardial fibrosis; coronary occlusion \\
\hline 61 & $\mathbf{F}$ & 1,432 & Coronary thrombosis \\
\hline 61 & $\mathbf{M}$ & 1,500 & Empyema; carcinoma of oesophagus \\
\hline 62 & $\mathbf{M}$ & 1,735 & $\begin{array}{l}\text { Left ventricular failure; hypertensive } \\
\text { heart disease }\end{array}$ \\
\hline 64 & $\mathbf{M}$ & 1,250 & Cerebral thrombosis \\
\hline 69 & $\mathbf{M}$ & 1,814 & Cerebral haemorrhage \\
\hline 69 & $\mathbf{M}$ & 921 & Air embolism; cut wounds of throat \\
\hline 72 & $\mathbf{M}$ & 1,145 & $\begin{array}{l}\text { Cardiac and renal failure; thrombosis of } \\
\text { abdominal aortic aneurysm }\end{array}$ \\
\hline 89 & $\mathbf{F}$ & 964 & Myocardial fibrosis; coronary occlusion \\
\hline
\end{tabular}

Received for publication 15 March 1967.

\section{TABLE II}

GROUP 3 CASES

Age Sex $\begin{aligned} & \text { Liver } \\ & \text { Weight (g.) }\end{aligned} \quad$ Cause of Death Given by Pathologist

\begin{tabular}{|c|c|c|c|}
\hline 15 & $\mathbf{M}$ & 1,460 & $\begin{array}{l}\text { Multiple injuries: subdural and cerebral } \\
\text { haemorrhage }\end{array}$ \\
\hline 19 & $\mathbf{F}$ & 1,644 & $\mathrm{CO}$ poisoning: fire fumes \\
\hline 30 & $\mathbf{F}$ & 1,701 & Barbiturate overdose \\
\hline 45 & $\mathbf{F}$ & - & $\begin{array}{l}\text { Cerebral haemorrhage due to ventri- } \\
\text { culography }\end{array}$ \\
\hline 61 & $\mathbf{M}$ & 1,520 & Renal failure: chronic pyelonephritis \\
\hline 64 & $\mathbf{M}$ & 1,304 & Acute on chronic bronchitis \\
\hline 66 & $\mathbf{F}$ & 1,489 & Dissecting aneurysm of aorta \\
\hline 66 & $\mathbf{M}$ & 1,525 & $\begin{array}{l}\text { Left ventricular failure, coronary athe- } \\
\text { roma }\end{array}$ \\
\hline 68 & $\mathbf{M}$ & 1,418 & Coronary thrombosis \\
\hline 70 & $\mathbf{F}$ & 1,020 & Hypertension \\
\hline 72 & $\mathbf{F}$ & 468 & Uraemia \\
\hline 76 & $\mathbf{M}$ & 936 & Coronary thrombosis \\
\hline 78 & $\mathbf{F}$ & 1,332 & Empyema; pneumonia \\
\hline 78 & $\mathbf{M}$ & 880 & $\begin{array}{l}\text { Pneumothorax; chronic bronchitis and } \\
\text { emphysema }\end{array}$ \\
\hline 80 & $\mathbf{F}$ & 1,115 & Pulmonary embolism \\
\hline 80 & $\mathbf{M}$ & 1,219 & Ruptured aneurysm of thoracic aorta \\
\hline 86 & $\mathbf{M}$ & & Myocardial fibrosis; coronary occlusio \\
\hline 93 & $\mathbf{F}$ & 950 & Myocardial fibrosis \\
\hline
\end{tabular}

male and 24 female. In none was there primary liver disease, cholelithiasis, peritonitis, peritoneal adhesion in the liver area, or metastatic carcinoma involving the liver. No cases in which a section from deep in the right lobe of the liver subsequently showed significant abnormalities other than congestion or fatty change were included in the series. The age of subjects ranged from 3 months to 93 years. Most of the patients died of cardiovascular disease. Summarized causes of death given by the pathologists carrying out the necropsies are shown in Tables I and II, together with the age, sex, and liver weight.

Blocks of liver approximately $1.5 \mathrm{~cm}$. across were taken from three sites at the inferior edge and one from deep in the right lobe as shown in Figure 1. The blocks were fixed in $10 \%$ neutral formol saline and embedded in paraffin. Sections, $5 \mu$, were stained with Harris's haematoxylin and with the Martius scarlet blue method (Lendrum, 
Fraser, Slidders, and Henderson, 1962). Reticulin fibres were impregnated by the method of Gordon and Sweet.

\section{RESULTS}

Macroscopically the livers appeared normal apart from venous congestion or mild fatty change. A prominent Riedel's lobe was noted in three cases.

According to the histological appearances, the livers were allocated to three groups (Table III).

\section{TABLE III}

DISTRIBUTION OF CASES BY HISTOLOGICAL APPEARANCES OF LIVER

\begin{tabular}{lccc} 
& Group 1 & Group 2 & Group 3 \\
\hline Male & 24 & 15 & 9 \\
Female & 9 & 6 & 9 \\
Total & 33 & 21 & 18
\end{tabular}

Group 1 livers were those in which the architecture was essentially similar in all four sections studied, including the one from deep in the right lobe. In the other two groups there was more fibrous tissue in the capsule or subcapsular area. In nine of the 21 livers of group 2 all sections from the liver edge were similar. The remaining 11 cases were allocated to group 2 on

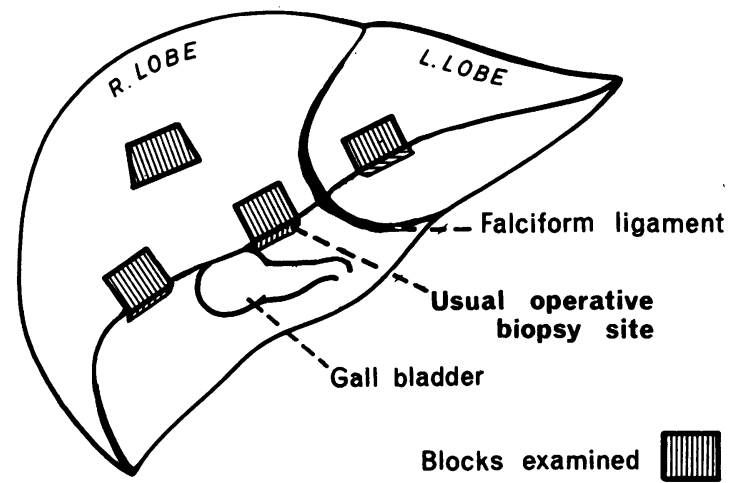

FIG. 1. Sites of blocks examined.

the basis of the most fibrotic of the three sections. The appearances at the usual biopsy site (Fig. 1) were representative of the group in 18 of the 21 cases. In group 3,10 of the 18 cases showed differences between the three liver edge sections but the usual biopsy site was representative in 16.

GROUP 1 In this group were included cases in which the liver capsule was regular and thin. In the subcapsular area, portal zones and central veins were

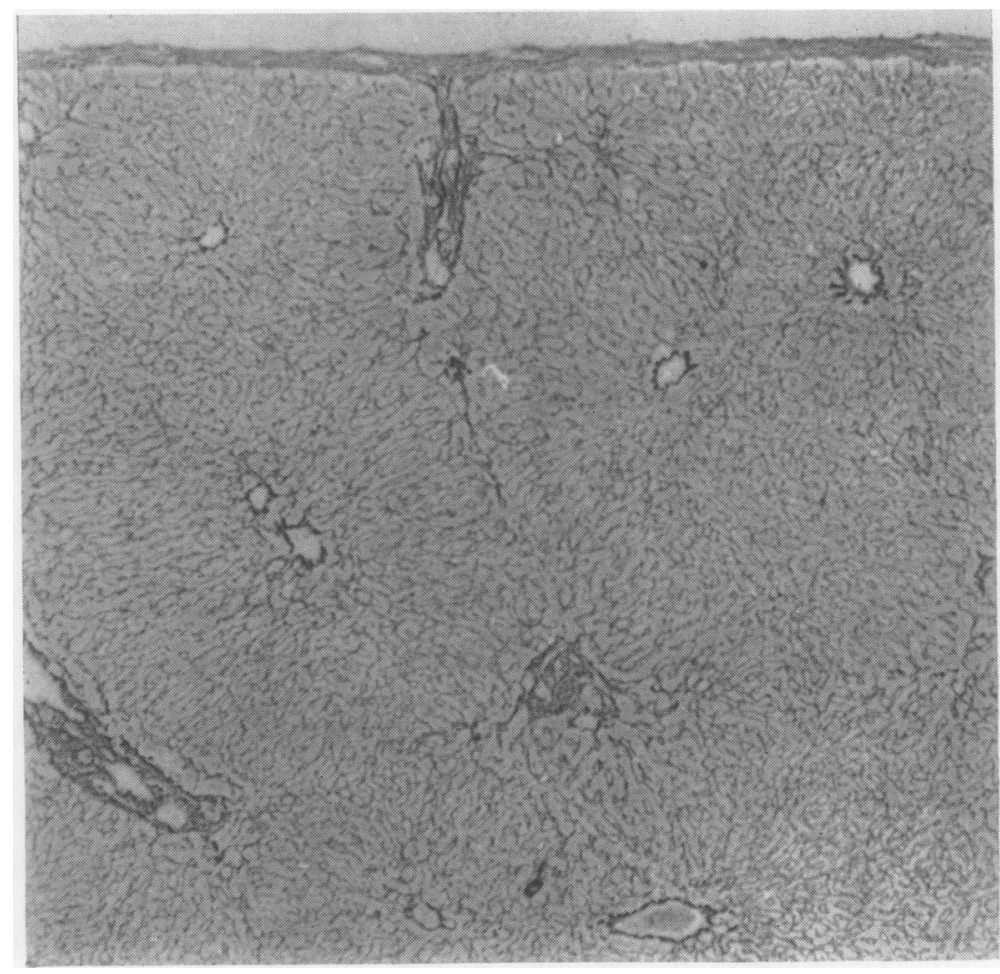

FIG. 2. Group 1 liver, showing thin capsule and evenly spaced vessels. Reticulin $\times 40$. 


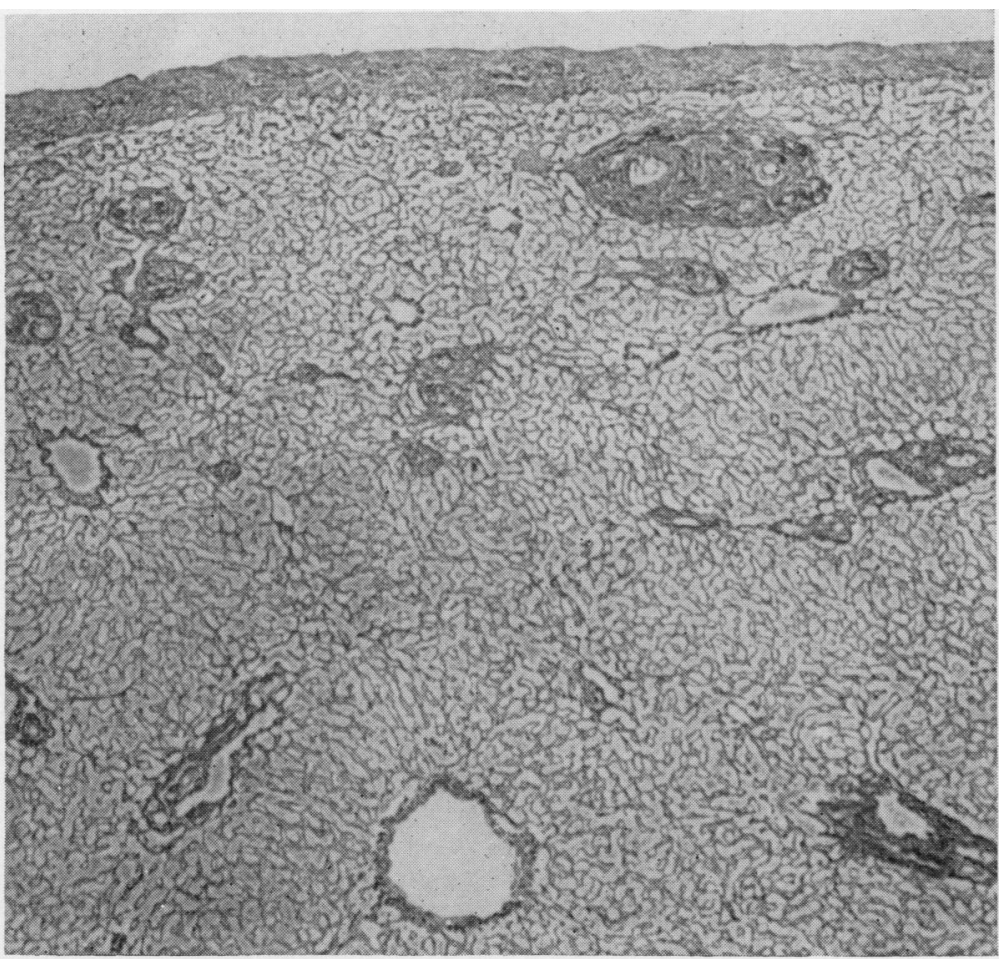

FIG. 3. Group 2 liver. There is more fibrous tissue in capsule and portal areas and vessels show crowding. Reticulin $\times 40$.

evenly spaced and lobules were easily defined (Fig. 2). Thirty-three of the 72 cases $(46 \%)$ fell into this group, 24 of them male and nine female. The ages ranged from 3 months to 84 years.

GROUP 2 (TABLE I) In this group there was crowding of central veins and portal zones in the subcapsular area, and lobules were reduced in size (Fig. 3). In a few of the cases short slender septa extended from portal zones but did not reach central veins or dissect lobules to any appreciable extent. The liver capsule was thin and regular, or irregularly thickened and folded. Crowding of portal and central structures was more severe in those livers having a thickened capsule. The group comprised 21 of the 72 cases $(29 \%), 15$ of them male and six female. The ages ranged from 20 years to 89 years.

GROUP 3 (TABLE II) Cases in group 3 showed crowding, formation of septa, and capsular thickening as in group 2 but often to a greater degree. There was an increase in reticulin and collagen in some portal and central areas. Thin septa joined portal tracts to central veins and occasionally islands of parenchyma appeared to be isolated by fibrous tissue (Fig. 4). The capsule was diffusely or focally thickened in most instances but appeared thin and regular in a few. Focal areas of capsular thickening contained vessels, ducts, and clumps of liver cells. Large conducting vessels and ducts, occasionally seen in all livers, were common in group 3 livers in the subcapsular area. At a distance of $2 \mathrm{~mm}$. or more from the capsular surface liver architecture was as described for groups 1 or 2 (Fig. $5)$. Eighteen cases of the $72(25 \%)$ were allocated to group 3 , nine male and nine female. The ages ranged from 15 years to 93 years.

OTHER FINDINGS Fatty change and congestion were common, especially in older subjects. In a few cases there were excess mononuclear cells in portal zones.

In six cases $(8 \%)$ microhamartomas (von Meyenburg complexes) were found (Fig. 6). In one case a microhamartoma was immediately subcapsular while in the others the lesions were related to portal zones. Multiple microhamartomas were seen in one of the six cases.

\section{DISCUSSION}

The results of the present study show that in a minority of cases a considerable amount of fibrous tissue is present in and near the capsule in an otherwise apparently normal liver. In some livers allocated to group 3 in our series there was indeed a s uperficial resemblance 


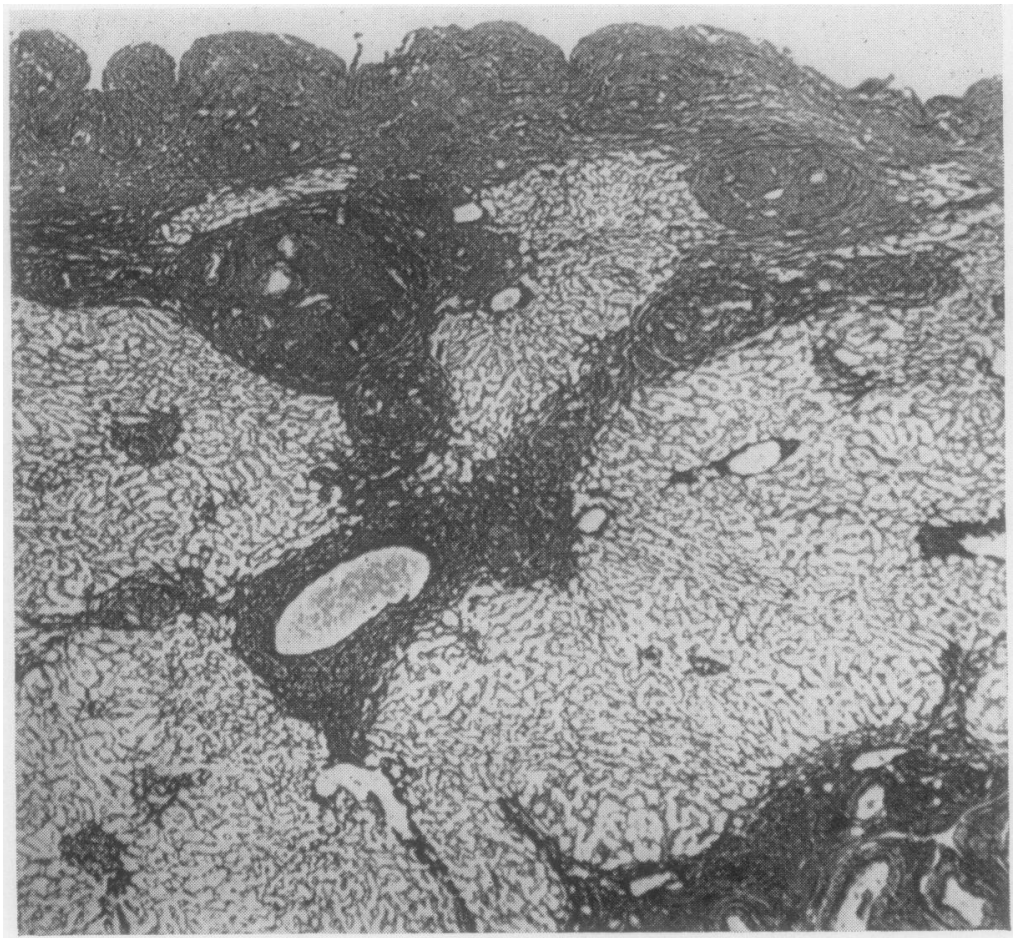

FIG. 4. Group 3 liver. The

capsule is thick and irregular, septa are seen, and islands of parenchyma appear to be isolated. $\omega$ Reticulin $\times 40$.

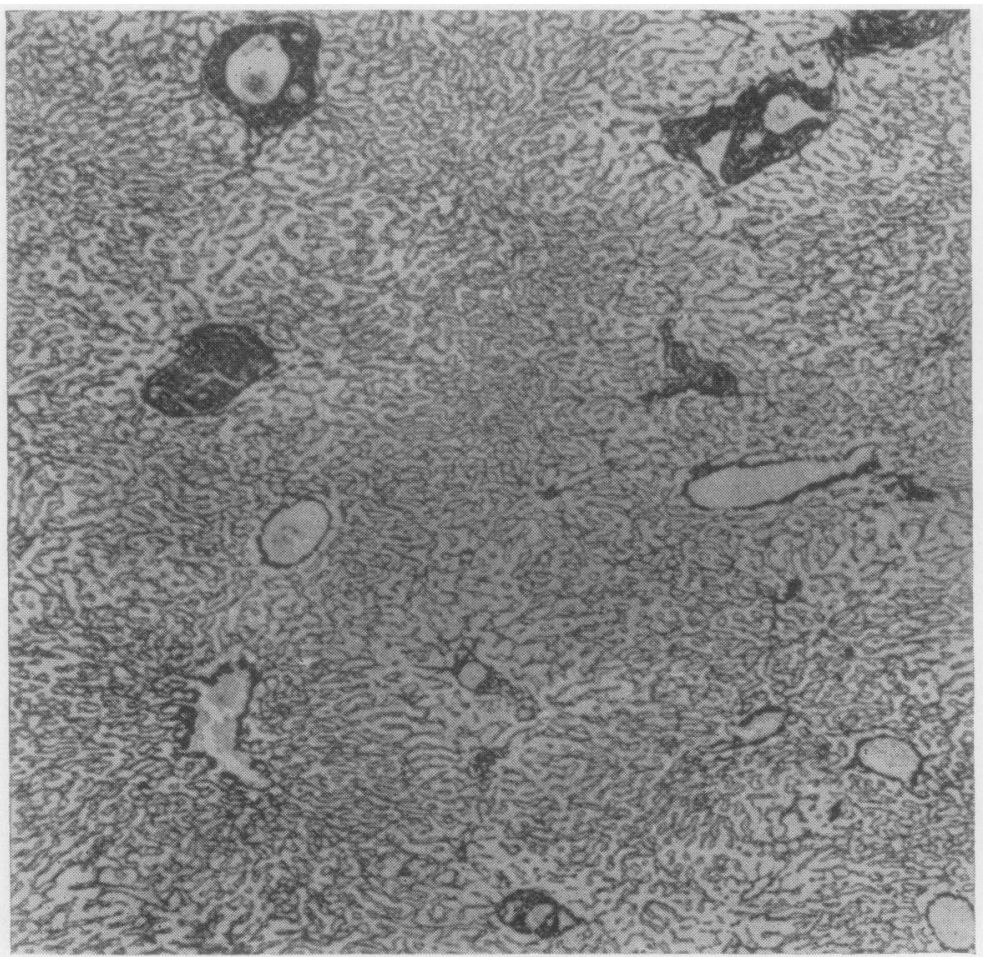

FIG. 5. Group 3 liver. In the deeper: part of the section shown in Fig. 4 the septa are not seen. Reticulin $\times 40$. 


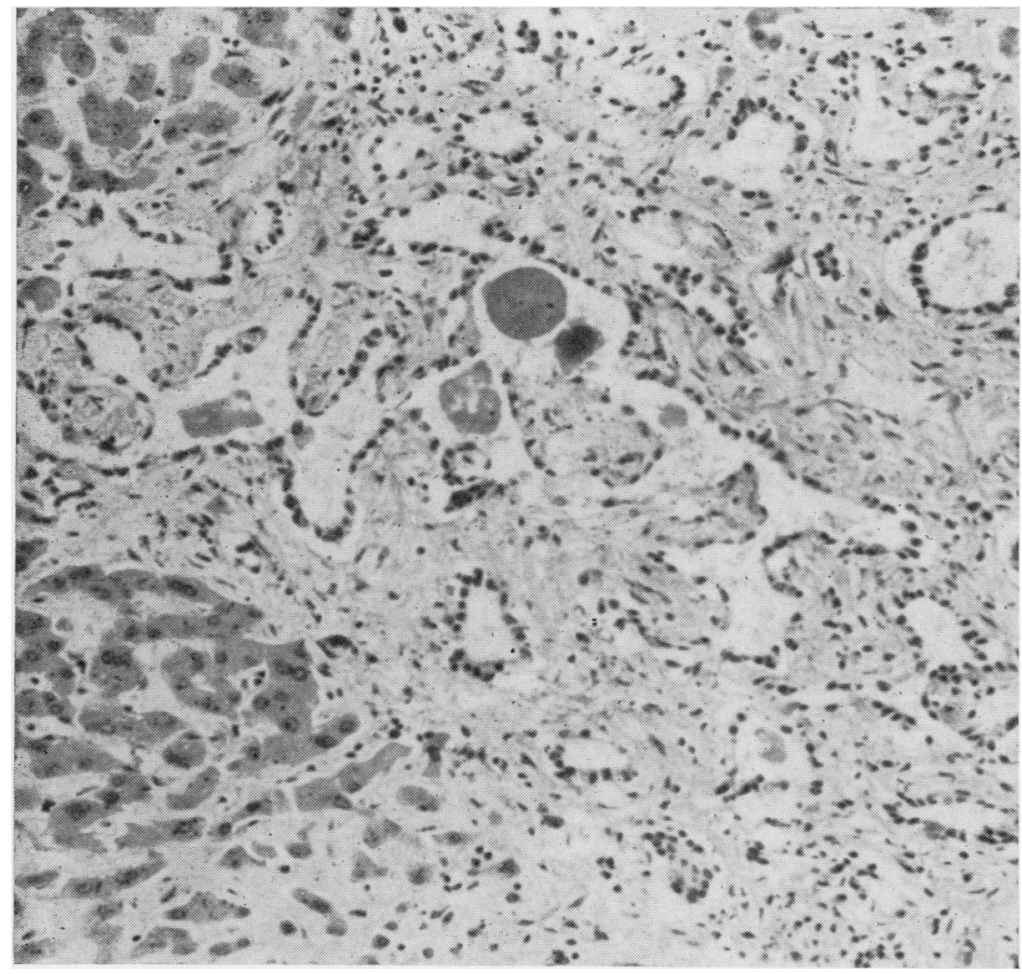

FIG. 6. A microhamartoma

(v. Meyenburg complex) showing ducts containing bile and set in mature fibrous tissue.

Haematoxylin and eosin $\times 160$

FIG. 7. Macronodular cirrhosis of incomplete septal type. Slender septa extend deep into the liver. There is distortion of veins and of the reticulin pattern. Reticulin $\times 40$.

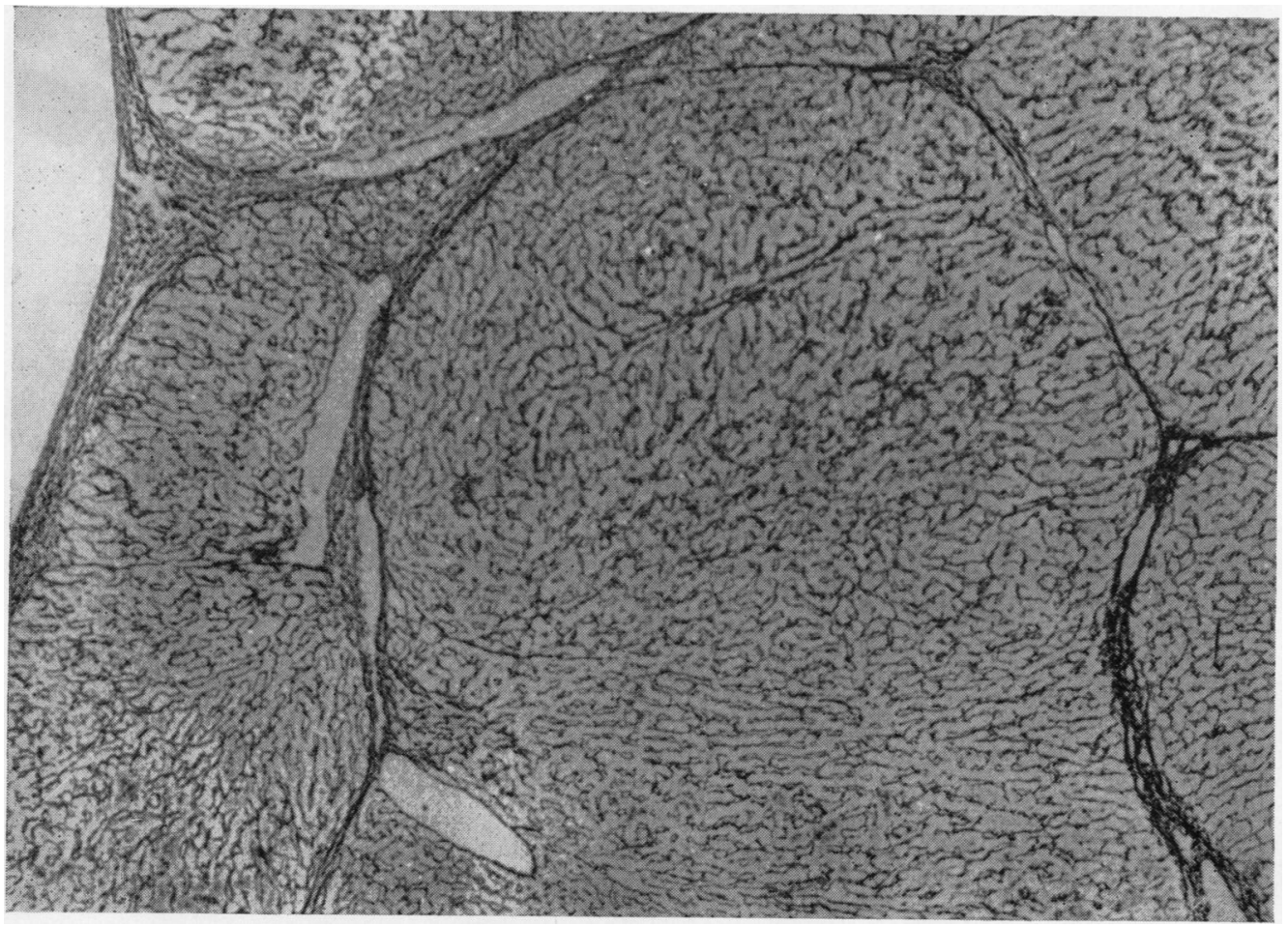


to macronodular cirrhosis of the incomplete septal type (Popper, 1966). Confusion should not, however, arise, since the increased fibrous tissue was in all cases confined to the immediately subcapsular zone. This zone forms only the superficial part of most operative wedge biopsies. Little or no increase in fibrous tissue was seen in the deeper parts of the sections examined. In true nodular cirrhosis, on the other hand, septa are present at all depths and there are other abnormalities, such as distortion of efferent veins by septa (Fig. 7). The septa joining portal and central areas in group 3 were uncommon and were not consistently found throughout the sections. Large conducting vessels and portal tracts were easily recognized and not confused with cirrhotic septa.

We are thus unable to support the conclusion of Metzler (1925) and Enders (1926) that wedge biopsy in adults has a limited diagnostic value because subcapsular fibrous tissue leads to confusion between normal and fibrotic livers. Metzler described 26 cases and Enders 126 cases. In the latter series about threequarters showed subcapsular excess of connective tissue. Some of the cases, however, had conditions such as peritonitis, appendicitis, or carcinomatosis in which capsular thickening was to be expected. The proportion with excess fibrous tissue would presumably have been lower by our criteria. Metzler in his series of 26 cases noted that the subcapsular changes increased with age. Enders, however, found fibrosis as early as the second decade. Similarly in our series group 3 appearances were seen in two subjects aged 15 and 19 years.

Although we refer above to 'changes', we have no firm evidence that the larger amounts of fibrous tissue are acquired during adult life. The appearances are a least partly explained by a proximity to the capsule of large blood vessels and bile ducts. Habighorst (1964) attributed the presence of large vessels within a thick $\frac{\infty}{D}$ ened capsule to physiological regression of liver, par $\frac{\mathbb{D}}{\square}$ enchyma during the development of the organ, and ton pathological pressure. It may be that neonatal liver cell degeneration due to circulatory changes and anoxia (Emery, 1952; Gruenwald, 1949) plays a part in the genesis of the increased fibrous tissue seen in oure cases, but this mechanism does not explain the cap용 sular and subcapsular localization. The possibilitiesi remain that the structural anomalies result from as yet undetected pathological factors, or that they represent $v$ variation in the normal microscopical anatomy of the liver.

We are grateful to Professor K. R. Hill and the staff of the Morbid Anatomy Department of the Royal Free Hospital, and to Professor F. E. Camps, for access to material. We thank Miss P. George and Dr. E. McLean for advice ando discussion and Miss B. Meyrick for technical assistance

\section{REFERENCES}

Emery, J. L. (1952). Arch. Dis. Childh., 27, 558.

Enders, W. (1926). Beitr. path. Anat., 76, 215.

Gruenwald, P. (1949). Amer. J. clin. Path., 19, 801.

Habighorst, L. V. (1964). Acta hepato-splenol. (Stuttg.), 11, 149.

Lendrum, A. C., Fraser, D. S., Slidders, W., and Henderson, R. (1962) J. clin. Path., 15, 401.

Metzler, F. (1925). Langenbecks Arch. klin. Chir., 134, 794.

Popper, H. (1966). In Controversy in Internal Medicine, edited by을 F. J. Ingelfinger, A. S. Relman, and M. Finland, p. 233. Saunders, Philadelphia and London. 